\title{
CONSUMER PREFERENCES TOWARDS AYURVEDA SERVICES IN INDIRANAGAR, BANGALORE
}

\author{
Umesh Chandra \\ PhD Scholar, Jain University, Bangalore-India \\ umeshchandra07@yahoo.com
}

\begin{abstract}
Lifestyle oriented Physiological and Psychological problems are increasing in recent times, especially among the younger generation because of increased work pressure and competition. People are looking for remedies and different health care solutions. Ayurveda is one of the ancient practices used in India to overcome many health care problems. The relevance of Ayurveda solutions is more in cosmopolitan cities because of challenging social and working environment. The organizations which provide Ayurveda solution, practices traditional methods and are mostly restricted to the local population, very few organizations have branches in countries other than in India. Some of the Ayurveda organizations focus on formulations, while some are in to services like Body Massage, Facial, Foot Treatment, Stress Management etc.,. The benefits of Ayurveda are recognized by many developing countries. It is important to know how many people have recognized the benefits of Ayurveda, to identify the gaps and find the solutions. In recent years, India has emerged as one of the destinations for medical tourism. Ayurveda can play a major role in medical tourism because of the expertise and affordable price. This research was done to know the potential of Ayurveda services in cosmopolitan population. It was conducted in Bangalore city to know the awareness and usage of Ayurveda services as a remedy for common lifestyle oriented Physiological and Physiological problems. The study is sponsored by Vaidyaratnam Ayurveda Services.
\end{abstract}

Keywords: Ayurveda Services, Consumer Awareness, Stress Management, Medical Tourism $* * *$

\section{INTRODUCTION}

In recent years, lifestyle oriented health problems are increasing, especially in the youngsters due to increased ambitions regarding career and their thirst to achieve high very early in life. To overcome these physiological and psychological problems, people are searching for avenues other than allopathic practices. Among them, Ayurveda services are one of the major practice which many people because it claims of very less or no side effects.[1]

In developed and developing countries, the role of traditional and complementary medicine is gaining importance which has been recognized by the World Health Organization. However, very few studies are done so far to understand the scenario. It is important for developing nations because traditional medicines are cost effective and can be easily administered. In some countries, these traditional methods, along with modern methods, have been practiced.

In India, along with Allopathy, Ayurveda, Homeopathy, and Unani health care practices are practiced. The Ayurveda system of medicine is having a presence in all strata of Indian society due to its ease of availability, affordability and safety. Ayurveda system of medicine is having the support of both central and state governments through various agencies. This is also helpful to overcome shortage of allopathic doctors in the country. ${ }^{[2]}$

\begin{abstract}
About Ayurveda system of medicine:
Ayurveda can be defined as a system, which uses the inherent principles of nature, to help maintain health in a person by keeping the individual's body, mind and spirit in perfect equilibrium with nature. It is one of the oldest medical practice in the Indian subcontinent. Knowledge of Ayurveda was passed from Guru/Teacher to disciple, later on, the knowledge was confined in the form of books. It is comprehensively documented in 'Charaka Samhita' and 'Sushruta Samhita'. Ayurveda practice has a holistic approach towards disease, unlike modern medicine. It deals with mental, spiritual, and physiological body complex along with social aspects of the human being.
\end{abstract}

The Philosophy of Ayurveda is based on five great elements theory called Panchmahabhutas. These five elements are represented in the form of Tridosha i.e Vatha, Pitta and Kapha. The mental and spiritual attributes are described as Satva, Rajas, and Tamas. Ayurveda considers the human being as combinations of three doshas, five elements, seven body tissues, five senses with sensory and motor functions, mind, intellect and soul. ${ }^{[3]}$

\footnotetext{
About Vaidayaratnam health care Ltd:

It is founded by Thaikkattu Mooss family, which contributed Ayurveda science significantly and hails from Kerala state where Ayurveda science is more popular. The family is having profound knowledge in all eight branches of Ayurveda, hence, bearing the title Ashtavaidyan. The splendid tradition of Thaikkattu mooss family begins with
} 
Sri Narayana Mooss and Ittiravi Mooss of the $19^{\text {th }}$ century . In 1924 Ashtavaidyan Narayana mooss was awarded with the title of Vaidayaratnam by Lord Reading, the then viceroy of India. Ashtavaidyan Sri E.T. Neelakandhan Mooss was awarded with Padmasri for his contribution in the field of Ayurveda. Vaidayaratnam group is headed by Ashtavaidyan Sri E.T Narayana Mooss, who is chairman and MD. He has been awarded with a number of awards Akshya Puraskar, Chikitsak Guru, Swadeshi Puraskar, PADMABHUSHAN, Best Acharya, to name a few.

\section{Scope of Ayurveda In Medical Tourism:}

India is one of the favorite destinations for medical tourism, specially, among underdeveloped countries because of expertise doctors, sophisticated hospitals and low cost of treatments. Ayurveda, to be a part of their itinerary, must work towards aggressive marketing and awareness programs through publishing details of Ayurveda Hospitals with core competencies and examples of different treatment procedures. It is also important to highlight external procedure of Ayurveda, Panchakarma and lifestyle management. Procedures like Vamana, Virechana, Basti and Nasya etc., are the modalities of the treatment which cannot be compelled in any sense with contemporary science due to its strong therapeutic preventative and long lasting effect. The various surgical and parasurgical techniques of Ayurveda like Agnikarma, Raktamokhsana and Ksharakarma have immense power to heal recurrent carcinogenic conditions and diseases. Ayurveda aims at Swastyas swasthya rakhsana i.e. preventive aspects. The science is well recognized by west, thus led to various major modalities of treatment attracted by the west. ${ }^{[4]}$

\section{Objectives of study:}

The study is conducted to know preferences towards Ayurveda among cosmopolitan population. Other objectives involved to know the awareness of Ayurveda services and consumer satisfactions towards Ayurveda services.

\section{Research methodology}

Indira Nagar, Bangalore, is cosmopolitan and has a higher literacy rate as well as higher income population. The research is sponsored by Vaidyaratnam heath care which is a leading Ayurveda services provider in south India.

Sampling area is Indiranagar, Bangalore.

Sampling unit is any individual residing at Indiranagar

Sampling technique is simple random sampling

Sample size is 187

The required data was collected by survey method using structured questionnaire and collected in two days 23/05//2014 - 24/05/2014 from 10:30 am to 5:00 pm

Limitation:

1) The survey restricted to Indiranagar, Bangalore.

2) All Respondents are literate persons.

3) The Study was conducted on four Ayurveda services

\section{Observations and results}

Table -1. A table showing awareness of different health care services

\begin{tabular}{|l|l|}
\hline Type of health care service & No of respondents aware \\
\hline Homeopathy & 10 \\
\hline Allopathy & 175 \\
\hline Ayurveda & 38 \\
\hline Acupuncture & 4 \\
\hline
\end{tabular}

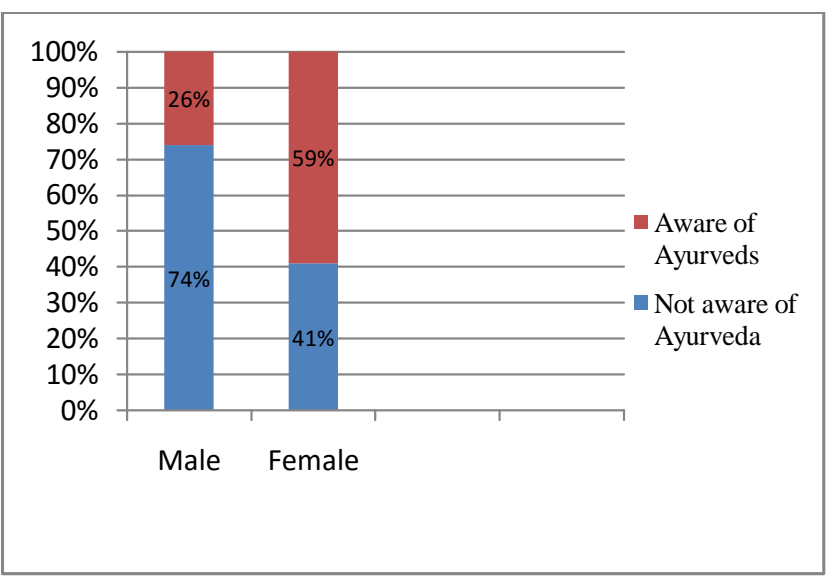

Fig- 1. Awareness of Ayurveda among Males and Females

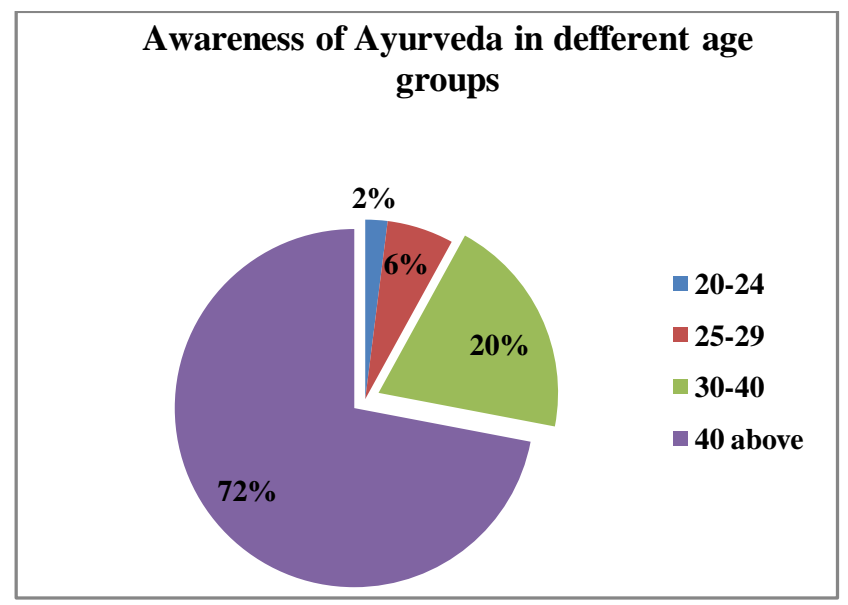

Fig-2

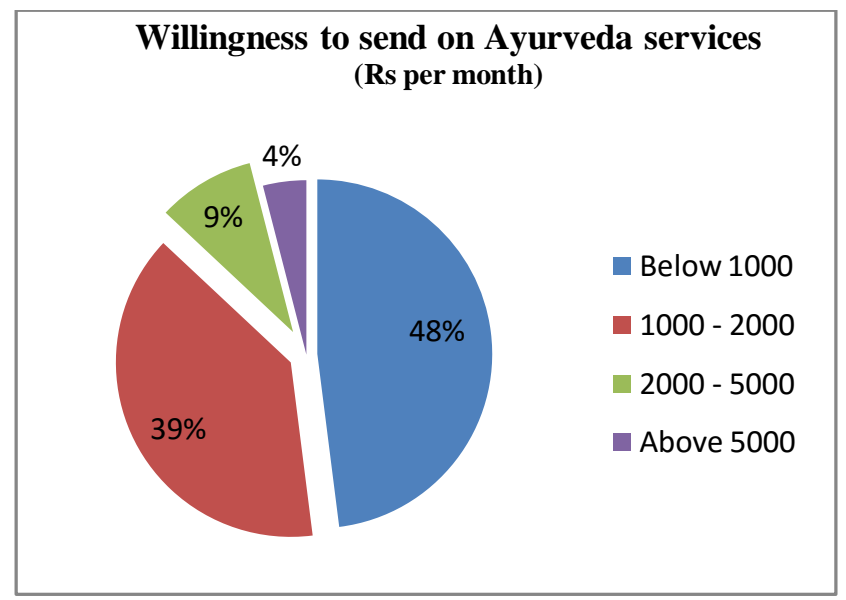

Fig-3 


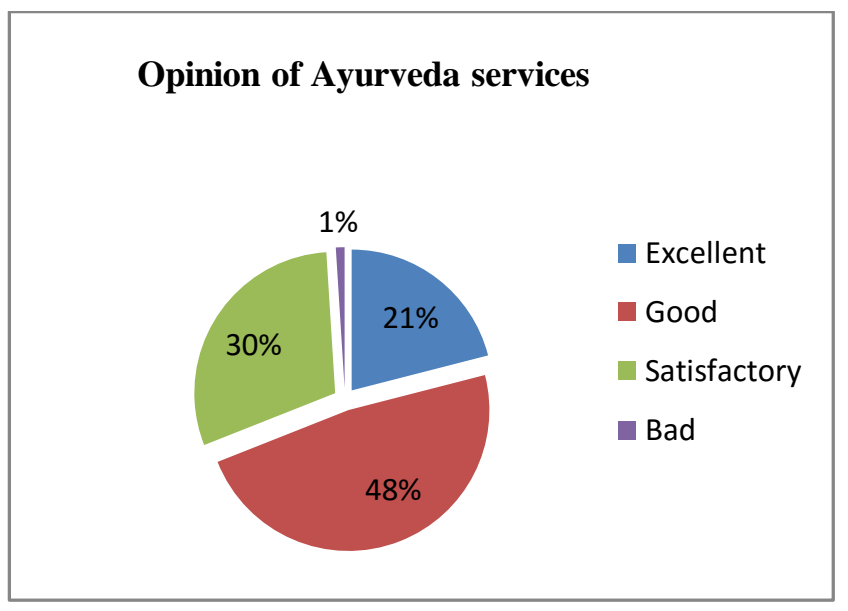

Fig-4

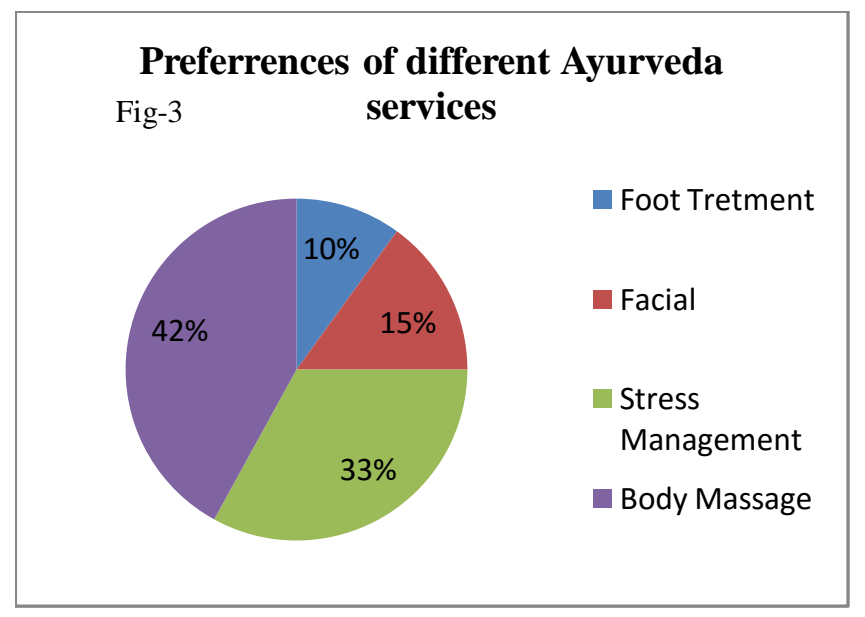

Fig-5

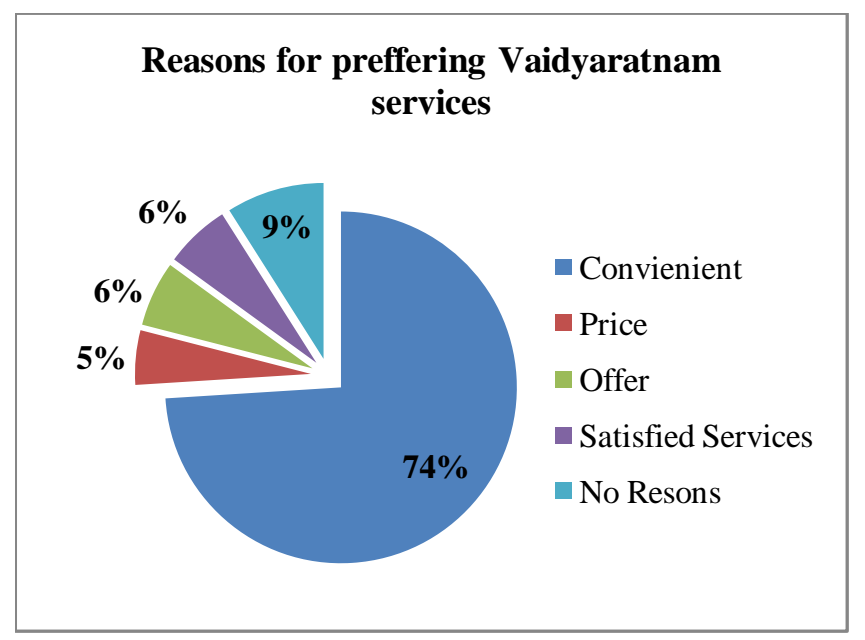

Fig-6

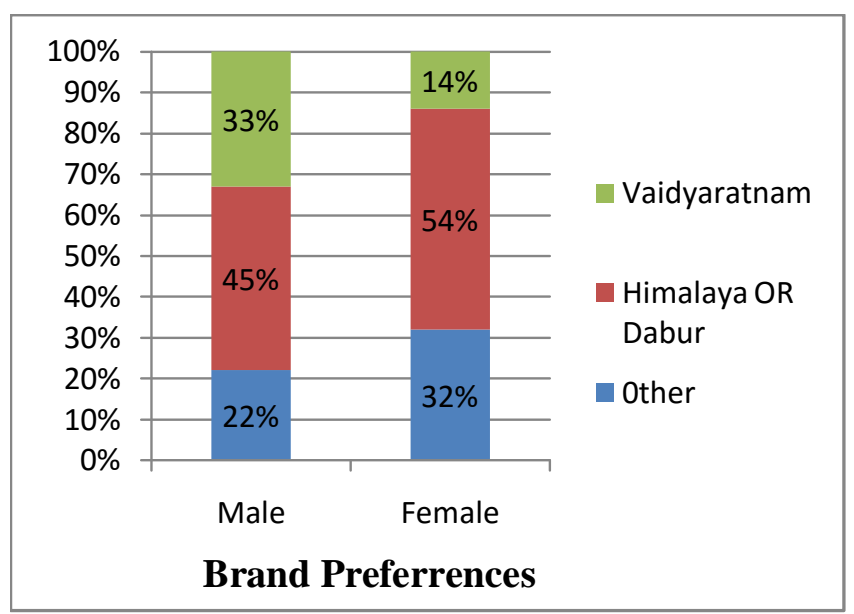

Fig-7

\section{FINDINGS}

Allopathic medical practice is known by maximum of the respondents which is on expected lines, where as few respondents are aware of Homeopathy and Ayurveda. Some respondents were aware of both Allopathy and Ayurveda and very few respondents were aware of Acupuncture. The awareness towards Ayurveda services is low among the male respondents and it is satisfactory among female respondents. A large number of the male population is unaware of Ayurveda. Hence, Ayurveda service providers must work on improving awareness with various programs as there are potential populations who suffer from work related health problems. Also, there is lots of scope to improve awareness of Ayurveda among the female population, even though a considerable number of female respondents are aware of it. The awareness of Ayurveda is more in the age group of above 40 years of age, whereas the awareness is not satisfactory among the age group of between 30-40 years and it is disappointing awareness among the young population of the age group of 25-29 years and 20-24 years. The need of improving awareness is very high among young population and immediate attention must be given to young male population.

It is important to know the amount of money, which the customers are willing to spend on the product/service and which will be helpful for the formulation of pricing strategies. $48 \%$ of respondents are willing to spend less than Rs 1000/month on Ayurveda services and 39\% of respondents are willing to spend Rs 1000-2000/month on Ayurveda services. Indiranagar is up market segment in Bangalore, in spite of this, the willingness to spend on Ayurveda service is less.

Nearly half of the respondents are having a good opinion about Ayurveda services, considerable no of respondents having a satisfactory and excellent opinion and very few have a bad opinion about Ayurveda services. This finding shows there is a need of converting good opinion into sales. Among the different Ayurveda services, most of them prefer body massage and a few prefer stress management, whereas very few prefer facial and foot care services. Ayurveda service providers should focus on body massage and stress 
management with care because it may send messages that Ayurveda service centers are massage centers.

Respondents prefer to use Vaidayaratnam Ayurveda services because of convenience, whereas very few prefer to use it for its satisfied services, offers and prices of services. A considerable number of male respondents and few female respondents prefer Vaidyaratnam compared to Himalya or Dabur or other Ayurveda services, whereas $22 \%$ of male and $32 \%$ of female respondents prefer to use other than the Himalaya, Dabur and Vaidyaratnam Ayurveda services.

\section{SUGGESTION}

1. There is a need to improve awareness of Ayurveda services, especially among the young male population.

2. The positive opinion about Ayurveda services must be converted into footfall to service centers and further as customers.

3. The focus must be towards stress management and cosmetic services of Ayurveda rather than the only Body Massage, or else Ayurveda service centers will become massage centers rather than the Ayurveda services providers.

\section{CONCLUSION}

The awareness of Ayurveda services is not high in cities like Bangalore, especially among the young male population. Many have restricted to the massage services of Ayurveda because they are not aware of the benefits of other Ayurveda services. It is a worrying factor because it is observed among literate people and in an upmarket area. Even though most of the people are positive about Ayurveda services, the benefits and importance of Ayurveda services are not reaching.

\section{REFFERENCES}

[1] Manjusha K. Borde, H. N. Lalan, Ipseeta Mohanty Ray, T. Sanjeeva Kumar Goud. HEALTH AWARENESS AND POPULARITY OF ALLOPATHIC, AYURVEDIC AND HOMEOPATHIC SYSTEMS OF MEDICINE AMONG NAVI MUMBAI POPULATION.World Journal of Pharmacy And Pharmaceutical Sciences, Volume 3, Issue 9, 783-788.

[2] Dr.MU.Subrahmanian, Dr.R.Prasanna Venkatesan, AWARENESS ON AYURVEDIC SYSTEM OF MEDICINE IN CHENNAI CITY, International Journal of Multidisciplinary Research Vol.1 Issue 2, June 2011, ISSN 22315780

[3] 3) Department (Evaluation Unit) Govt. Of National Capital Territory Of Delhi.

[4] Ashutosh Chaturvedi, MP Pujar, KM Ashwini, BS Praveen, RS Khatri. AYURVEDA IN MEDICAL TOURISM - GLOBAL SCENARIO, International conference on Global scenario of traditional system of Medicine Ayurveda, Agriculture and Education -2013 India
[5] Sunil Jawla, A.K. Gupta, Rachit Singla,Varun Gupta. General awareness and relative popularity of allopathic, Ayurvedic and homeopathic systems, Journal of Chemical and Pharmaceutical Research, 2009, 1 (1): 105-112

[6] Niraj Subrat, Meera Iyer and Ram Prasad, The Ayurvedic medicine industry: Current status and sustainability, Ecotech Services (India) Pvt. Ltd. 2002 New Delhi

[7] Kushagra Nagori, et.al, General Awareness On Allopathic, Ayurveda And Homeopathic System Of Medicine In Chhattisgarh, India. International Journal of Pharmacy and Pharmaceutical Sciences ISSN- 09751491 Vol 3, Suppl 4, 2011

[8] http://www.vaidyaratnammooss.com/pages.php?menu_i $\mathrm{d}=1$ 